\title{
Herpetofauna diversity and distribution based on the elevational range in West Java, Indonesia
}

\author{
TATANG SUHARMANA ERAWAN ${ }^{1}$, JIRJIZ JAUHAN ${ }^{3}$, TEGUH HUSODO ${ }^{1,2,3, \boldsymbol{v}}$, INDRI WULANDARI ${ }^{1,2,3}$, \\ DERI ACHMAD FAUZI ${ }^{3}$, ERRI NOVIAR MEGANTARA ${ }^{1,2,3}$, SYA SYA SHANIDA $^{3}$ \\ ${ }^{1}$ Department of Biology, Faculty of Mathematics and Natural Sciences, Universitas Padjadjaran. Jl. Raya Bandung-Sumedang Km. 21, Jatinangor, \\ Sumedang 45363, West Java, Indonesia \\ ${ }^{2}$ Program of Environmental Science, School of Graduates, Universitas Padjadjaran. J1. Dipati Ukur No. 35, Bandung 40132, West Java, Indonesia \\ ${ }^{3}$ Center of Environment and Sustainable Science, Directorate of Research, Community Services and Innovation, Universitas Padjadjaran. Jl. Sekeloa, \\ Coblong, Bandung 40132, West Java, Indonesia. Tel.: +62-22-2502176.`email: teguhhusodo2@unpad.ac.id
}

Manuscript received: 4 September 2021. Revision accepted: 22 September 2021.

\begin{abstract}
Erawan TS, Jauhan J, Husodo T, Wulandari I, Fauzi DA, Megantara EN, Shanida SS. 2021. Herpetofauna diversity and distribution based on the elevational range in West Java, Indonesia. Biodiversitas 22: 4308-4319. The herpetofauna discovery in West Java is still low and has not yet described the herpetofauna community's species diversity entirely and thoroughly in West Java. It experiences high anthropogenic impacts both from infrastructure and tourism activities. If left further, herpetofauna species will become extinct locally because of anthropogenic factors. Therefore, it is essential to reveal the diversity and distribution of herpetofauna species. This study aimed to show diversity and distribution based on the elevational range in West Java. Visual Encounter Survey in combination with the Auditory Encounter Survey was applied in this study. We found 74 species where the Colubridae family were found most commonly in the study sites. Of 74 species, four species have high conservation status, including Rhacophorus reinwardtii, Ophiophagus hannah, Varanus salvator, and Malayopython reticulatus. Besides, ten species were found to be endemic to Java and JavaBali. Based on elevation, herpetofauna is mainly located at elevations $<1000 \mathrm{~m}$ asl. The higher the height, the fewer the number of species found. In Amphibians, the highest number of species tend to be found at 400-1200 m asl and 1400-1700 m asl, while reptiles tend to be located at $400-900 \mathrm{~m}$ asl.
\end{abstract}

Keywords: Amphibians, auditory encounter survey, reptiles

\section{INTRODUCTION}

Amphibian diversity on Java Island has currently recorded 43 species of Amphibians (Riyanto 2014). The diversity of Amphibians in the ecoregions of the western part of the mountainous rainforests of Java is 26 species (Das and van Dijk 2013) or $60.5 \%$ of all species on Java, while reptiles in the ecoregion of western Java mountain rainforests are 81 species (Das and van Dijk 2013) or $47.4 \%$ of 171 species of reptiles on Java (Uetz et al. 2018).

Amphibians can indicate biodiversity and local pressure on the environment because amphibians are sensitive to environmental changes, e.g., water pollution (Burlibaşa and Gavrilă 2011; Carlsson and Tydén 2018; Priambodo et al. 2019). Herpetofauna has declined in abundance, diversity, and some species are even threatened with extinction because of rapid urbanization and agriculture intensification, leading to the invasion of alien species and habitat loss (Carpio et al. 2015; Cassani et al. 2015), and over-exploitation of herpetofauna for industry, consumption, and pet trading (Natusch and Lyons 2012; Shaney et al. 2017).

In South and Southeast Asia, amphibians and reptiles research has not received much attention in terms of ecological aspects. Moreover, intensive field surveys are rarely conducted and published (Karthik et al. 2018). Knowledge of herpetofauna diversity is essential because these animals: (i) play a vital role in maintaining the sustainability of ecosystems, (ii) aid human socioeconomics through utilization as tourism objects (Riyanto et al. 2019a), (iii) act as a pest controller (rat and insect eaters), and (iv) provide germplasm (Cahyadi and Arifin 2019).

The herpetofauna discovery in West Java is still low and has not yet described the herpetofauna community's species diversity entirely and thoroughly in West Java. The region experiences high anthropogenic impacts both from infrastructure and tourism activities. Research on amphi-bians and reptiles in Java that had been conducted, e.g., Riyanto et al. (2014); Riyanto and Kurniati (2014); Riyanto et al. (2015); Hartmann et al. (2016); Kieckbusch et al. (2016); Hamidy et al. (2018); Riyanto et al. (2019b); and Cahyadi and Arifin (2019) had revealed that amphibian and reptile diversity in the region is still underestimated. Therefore, it is essential to show the diversity of herpetofauna species to support conservation efforts.

The general trend shows that herpetofauna species richness decreases as elevation increases (Scott 1976). In Monteverde, species at lower elevations are significantly higher than at higher elevations (Hayes et al. 1989). Stevens (1992) revealed that species richness is lower at higher elevations as highland species are more specialized and lower tolerance to biotic and abiotic conditions changes. Populations at higher elevations are put at 
increased risk for extinction because geographic range size decreases as elevation increases (Pounds et al. 2006).

This study aims to reveal herpetofauna diversity and distribution based on the elevational range in West Java. This study was carried out in non-conservation areas such as Cisokan, Ciletuh, and Darajat. In contrast, Kamojang and Gunung Salak were carried out both in the conservation and non-conservation areas. According to Samitra and Rozi (2020), herpetofauna research had been conducted primarily on conservation areas; therefore, research on the herpetofauna diversity outside conservation areas is needed.

\section{MATERIALS AND METHODS}

\section{Study area}

The study was conducted in five locations in West Java Province, Indonesia in 2017-2018, including Cisokan in West Bandung District (February 2017), Ciletuh in Sukabumi District (March 2017), Kamojang in Garut District (July 2017), Darajat in Garut District (May 2018), and Gunung Salak between Sukabumi and Bogor District (July 2018), West Java (Figure 1).

West Java Province is divided into steep mountainous regions in the South with an altitude of more than $1500 \mathrm{~m}$ asl, the area of the hillsides in the middle part of West Java with a height of 100-1500 m asl, in the North with a height of $0-10 \mathrm{~m}$ asl. West Java is located between $5^{\circ} 50^{\prime}-7^{\circ} 50$ 'SL and $104^{\circ} 48^{\prime}-108^{\circ} 48$ 'EL. The area of West Java is $35,377.76 \mathrm{~km}^{2}$. The Java Sea borders the Northern part of West Java Province. The Indian Ocean borders the Southern part. Banten Province and DKI Jakarta border the Western region. Central Java Province borders the Eastern part.

\section{Procedures}

The study's time varied, such as Cisokan conducted for 21 days, while other locations were carried out for eight days. Herpetofauna sampling was carried out during the day and night using the Visual Encounter Survey/ VES time-constrained method. At least two observers carry out VES by walking slowly and carefully following the existing transect paths, both footpaths or streams, to find the species on the surface of the ground, the surface of the rock, or perch on leaves and twigs. VES is carried out with five hours during the day (07.00 a.m.-10 a.m.; 02.00 p.m.04.00 p.m.) and three hours at night (08.00 p.m. -11.00 p.m.) on each transect. Boruah et al. (2016) revealed that a survey covered forest paths, woodlands, plantations, stream edges, agricultural fields, and bushes. For amphibians and nocturnal snakes, surveys were done thoroughly in all suitable habitats such as village roads, ponds, drains, and surroundings of old buildings, bushes near streams, under rocks and $\operatorname{logs}$, other water bodies, and arboreal habitats with the help of lights.

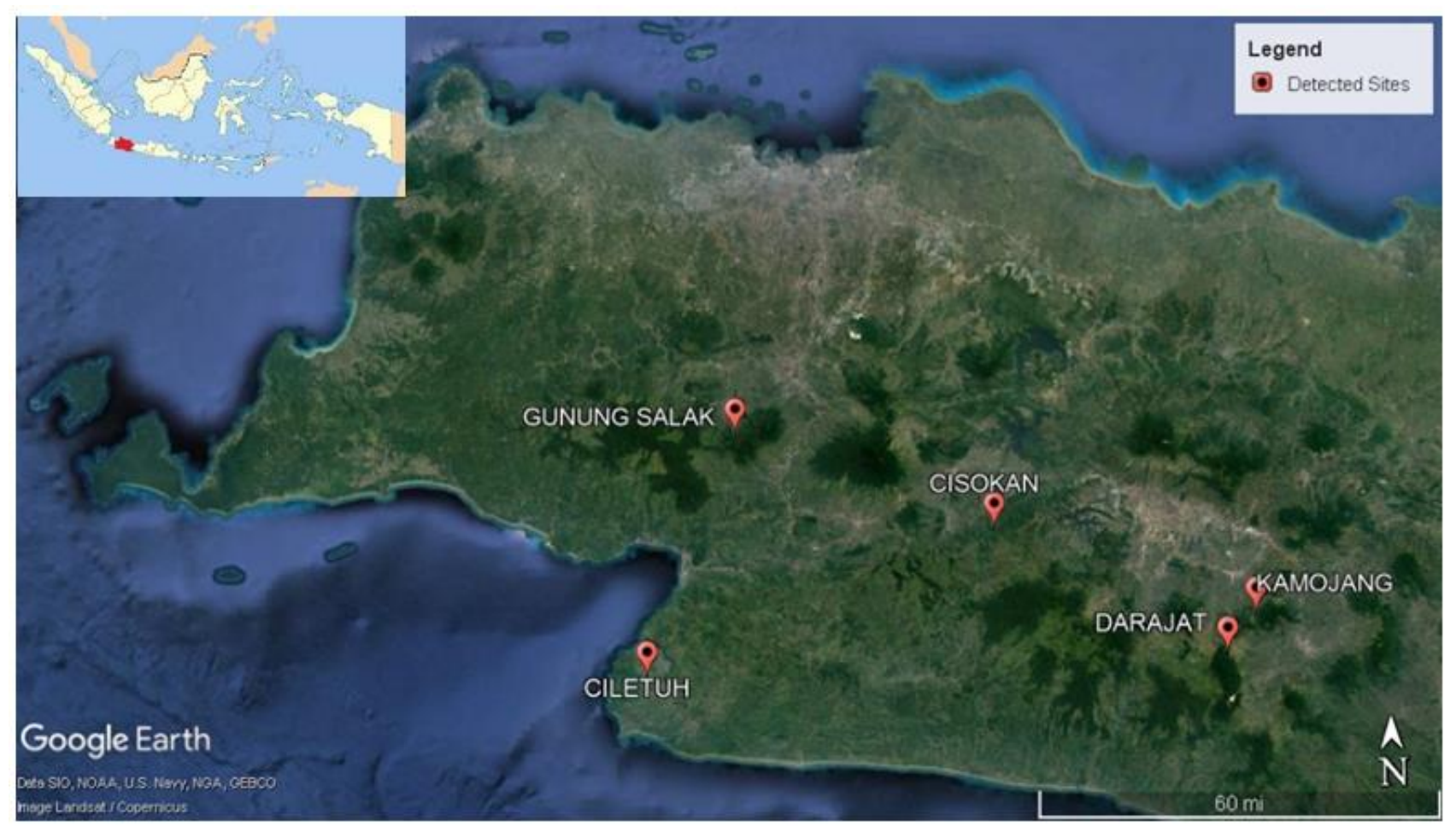

Figure 1. Study areas in West Java, Indonesia; Cisokan (48 M $746030.02 \mathrm{~m} \mathrm{E} 9231551.58 \mathrm{~m} \mathrm{~S}$ ); Ciletuh (48 M $661159.73 \mathrm{~m} \mathrm{E}$ 9198069.84 m S); Darajat (48 M 800811.68 m E 9200549.76 m S); Kamojang (48 M 808381.73 m E 9209763.04 m S); and Gunung Salak (48 M 683756.00 m E $9255797.00 \mathrm{~m} \mathrm{~S}$ ). 
VES is combined with opportunistic exploration methods (Riyanto 2011), and auditory encounter survey/audio strip transects to detect herpetofauna, especially those fossorial or small and hidden. Herpetofauna was identified and documented in situ. Voice recording is also carried out to support the identification process, primarily small or hidden species. Vega-Trejo et al. (2013) said that voice recording is also used to support the identification process, especially for small or hidden species. The recording is carried out on the surrounding environmental conditions, especially threats that harm herpetofauna. Pictures were taken for identification purposes.

Secondary data were also collected by taking interviews with the local people. Notes were made to observe each species' habitats, road kills, anthropogenic activities in the area, threats to the herpetofauna, the interaction between humans and snakes, etc. (Boruah et al. 2016). Herpetofauna was identified using the herpetofauna guidebook. Conservation status is referred to by the National Regulation of the Republic of Indonesia, IUCN (International Union for Conservation of Nature) RedList, and CITES (Convention on International Trade of Endangered Species).

\section{Data analysis}

Data was analyzed qualitatively. We recorded the number of species per locations and per elevation ranges.

\section{RESULTS AND DISCUSSION}

\section{Diversity of herpetofauna}

Seventy-four species of herpetofauna in West Java, especially Ciletuh, Cisokan, Kamojang, Darajat, and Gunung Salak, were found (Table 3; Figure 2). There were 24 amphibian species and 50 reptile species. Based on the number of species, the order Squamata is most commonly found in the sites. Of the 74 species, several species have a high conservation status, such as Reinwardti's Frog (Rhacophorus reinwardtii) with Near Threatened status, King Cobra (Ophiophagus hannah) with Vulnerable and Appendix II status, Javan Torrent Frog (Huia masonii) with Vulnerable status, Indonesian Bubble-nest Frog (Philautus vittiger) with Near Threatened status, Common Water Monitor (Varanus salvator), and Reticulated Python (Malayopython reticulatus) with status Appendix II (IUCN 2021; UNEP-WCMC (Comps.) 2021). In addition to conservation status, three species are also known as endemic to Java and Bali Island. The species that are endemic only to Java Island are ten species (see Table 1).

\section{Herpetofauna distribution based on elevational}

We found herpetofauna range from 0-2300 $\mathrm{m}$ asl where at an elevation of 400-900 m asl mainly found as many as 51 species, while at the highest height ranging from 1600$2300 \mathrm{~m}$ asl was found 16 species (Table 1). Various species were found at varying elevations. We can see in Table 4 that the species are more often found at elevations below $<1000 \mathrm{~m}$ asl. Besides, Table 4 can show several species that are only found at elevations $\geq 2000 \mathrm{~m}$ asl.
Table 1. Total number of species in West Java

\begin{tabular}{lccc}
\hline Sublocations & $\begin{array}{c}\text { Elevation } \\
\text { (m asl) }\end{array}$ & $\begin{array}{c}\text { Number of } \\
\text { amphibians } \\
\text { species }\end{array}$ & $\begin{array}{c}\text { Number of } \\
\text { reptiles } \\
\text { species }\end{array}$ \\
\hline Ciletuh & $0-500$ & 11 & \\
Cisokan & $400-900$ & 18 & 24 \\
Gunung Salak & $700-1500$ & 18 & 11 \\
Kamojang & $1400-1700$ & 10 & 6 \\
Darajat & $1600-2300$ & 20 & 17 \\
& & &
\end{tabular}

Source: Primary Data (2017-2018)

Table 2. Total number of species based on mountain forest subzone

\begin{tabular}{lcc}
\hline $\begin{array}{c}\text { Elevation range } \\
(\mathbf{m} \text { asl })\end{array}$ & $\begin{array}{c}\text { Number of } \\
\text { amphibians species }\end{array}$ & $\begin{array}{c}\text { Number of } \\
\text { reptiles species }\end{array}$ \\
\hline & & \\
$<1000$ & 22 & 45 \\
$1000-1500$ & 22 & 19 \\
$1500-2400$ & 18 & 13
\end{tabular}

Sources: van Steenis (2006), Primary Data (2017-2018)

Based on the mountain forest subzone by van Steenis (2006), 41 species were found at an elevation of 1000-1500 $\mathrm{m}$ asl (submontane) and a height of 1500-2400 $\mathrm{m}$ asl (montane), found 31 species (Table 2). At an elevation $<1000 \mathrm{~m}$ asl, 67 species were found to be the most common.

\section{Discussion}

In amphibians, the Dicroglossidae family had the highest species diversity (six species), while in reptiles, the Colubridae family had the highest species diversity (16 species) than other families. Of all amphibians and reptiles, Colubridae had the highest species diversity. The species of herpetofauna that have the most chance to be found continuously and increase the number of the herpetofauna species in West Java come from snake groups, considering that this group has the highest diversity among lower case for reptile groups in Java (Uetz et al. 2018).

The discovery varied in each location. Seven species were found in the five study sites, including Duttaphrynus melanostictus, Microhyla achatina, Chalcorana chalconota, Chalcorana rufipes, Polypedates leucomystax, Hemidactylus frenatus, and Eutropis multifasciata. Additionally, 11 species were found in only one of the five study sites. Dutaphyrnus melanoticus is a species of the family of Bufonidae that can be found in the human environment. Polypedates leucomystax can be found in areas with plants, such as forests, and even close to human settlements because this species needs light to prey on insects (Rozi and Samitra 2020). 
Table 3. Diversity of herpetofauna in West Java, Indonesia

\begin{tabular}{|c|c|c|c|c|c|c|c|}
\hline Class | Order | Family | Species & Common name & CLT & CSK & KMJ & DRJ & GS & $\begin{array}{l}\text { Conservation Stat. } \\
\text { IUCN } \quad \text { CITES }\end{array}$ \\
\hline \multicolumn{8}{|l|}{ AMPHIBIANS } \\
\hline \multicolumn{8}{|l|}{ ANURA } \\
\hline \multicolumn{8}{|l|}{ Bufonidae } \\
\hline Duttaphrynus melanostictus (Schneider, 1799) & Black-spectacled Toad & + & + & + & + & + & $\mathrm{LC}$ \\
\hline Ingerophrynus biporcatus (Gravenhorst, 1829) & Indonesian Toad & & + & & & & $\mathrm{LC}$ \\
\hline Phrynoidis aspera (Gravenhorst, 1829) & Java Toad & + & + & & & + & $\mathrm{LC}$ \\
\hline \multicolumn{8}{|l|}{ Megophryidae } \\
\hline Megophrys montana (Kuhl and van Hasselt, 1822) ${ }^{l}$ & Asian Spadefoot Toad & & & & + & + & $\mathrm{LC}$ \\
\hline Leptobrachium hasseltii (Tschudi, 1838) ${ }^{2}$ & Java Spadefoot Toad & & + & + & & + & LC \\
\hline \multicolumn{8}{|l|}{ Microhylidae } \\
\hline Microhyla achatina (Tschudi, 1838) ${ }^{l}$ & Javan Chorus Frog & + & + & + & + & + & $\mathrm{LC}$ \\
\hline Microhyla palmipes (Boulenger, 1897) & Pengalengan Rice Frog & & & + & + & + & $\mathrm{LC}$ \\
\hline Kaloula baleata (Muller, 1836) ${ }^{l}$ & Brown Bullfrog & + & & + & & & LC \\
\hline \multicolumn{8}{|l|}{ Dicroglossidae } \\
\hline Fejervarya cancrivora (Gravenhorst, 1829) & Asian Brackish Frog & + & + & & & + & $\mathrm{LC}$ \\
\hline Fejervarya limnocharis (Gravenhorst, 1829) & Asian Grass Frog & + & + & + & & & $\mathrm{LC}$ \\
\hline Limnonectes kuhlii (Tschudi, 1838) ${ }^{l}$ & Large-headed Frog & + & + & + & & + & LC \\
\hline Limnonectes macrodon (Dumeril and Bibron, 1841) & Malayan Wart Frog & + & + & + & & + & LC \\
\hline Limnonectes microdiscus (Boettger, 1892) & Indonesian Wart Frog & & + & + & & + & $\mathrm{LC}$ \\
\hline Occidozyga sumatrana (Peters, 1877) & Puddle Frog & & + & & & & $\mathrm{LC}$ \\
\hline \multicolumn{8}{|l|}{ Ranidae } \\
\hline Amnirana nicobariensis (Stoliczka, 1870) & Nicobar Island Frog & & + & + & + & + & $\mathrm{LC}$ \\
\hline Chalcorana chalconota (Schlegel, 1837) & Schlegel's Frog & + & + & + & + & + & LC \\
\hline Chalcorana rufipes (Inger, Stuart \& Iskandar, 2009) & & + & + & + & + & + & $\mathrm{LC}$ \\
\hline Huia masonii (Boulenger, 1884) ${ }^{I}$ & Javan Torrent Frog & & + & + & + & + & VU \\
\hline Odorrana hosii (Boulenger, 1891) & Hose's Frog & & + & + & & + & LC \\
\hline \multicolumn{8}{|l|}{ Rhacophoridae } \\
\hline Philautus vittiger (Boulenger, 1897) ${ }^{l}$ & Indonesian Bubble-nest Frog & & & & & + & NT \\
\hline Philautus aurifasciatus (Schlegel, 1837) ${ }^{l}$ & Java Bubble-nest Frog & & & + & + & + & $\mathrm{LC}$ \\
\hline Polypedates leucomystax (Gravenhorst, 1829) & White-lipped Tree Frog & + & + & + & + & + & $\mathrm{LC}$ \\
\hline Rhacophorus margaritifer (Schlegel, 1837) ${ }^{I}$ & Java Flying Frog & & & + & & + & LC \\
\hline Rhacophorus reinwardtii $\left(\right.$ Schlegel, 1840) ${ }^{l}$ & Reinwardti's Frog & & + & + & & + & NT \\
\hline \multicolumn{8}{|l|}{ REPTILE } \\
\hline \multicolumn{8}{|l|}{ TESTUDINES } \\
\hline \multicolumn{8}{|l|}{ Trionychidae } \\
\hline Dogania subplana (Geoffroy Saint-Hilaire, 1809) & Malayan Soft-shelled Turtle & & & & & + & $\mathrm{LC}$ \\
\hline
\end{tabular}




\section{SQUAMATA}

\section{Agamidae}

Bronchocela cristatella (Kuhl, 1820)

Bronchocela jubata (Dumeril \& Bibron, 1837)

Draco fimbriatus (Kuhl, 1820)

Draco volans (Common Flying Dragon) ${ }^{2}$

Gonocephalus chamaeleontinus (Laurenti, 1768

Gonocephalus kuhlii (Schlegel, 1851)

Pseudocalotes tympanistriga (Gray, 1831) ${ }^{I}$

\section{Gekkonidae}

Cyrtodactylus marmoratus (Griffith and Pidgeon, 1831)

Cyrtodactylus sp. (Gray, 1827)

Gehyra mutilata (Wiegmann, 1834)

Gekko gecko (Linnaeus, 1758)

Hemidactylus frenatus (Dumeril \& Bibron, 1836)

Hemidactylus garnotii (Dumeril \& Bibron, 1836)

Hemidactylus platyurus (Schneider, 1797)

Lacertidae

Takydromus sexlineatus (Daudin, 1802)

\section{Scincidae}

Eutropis multifasciata (Kuhl, 1820)

Lygosoma bowringii (Gunther, 1864)

Sphenomorphus sanctus (Dumeril \& Bibron, 1839)

\section{Varanidae}

Varanus salvator (Laurenti, 1768)

\section{Pythonidae}

Malayopython reticulatus (Schneider, 1801)

Colubridae

Ahaetulla mycterizans (Linnaeus, 1758)

Ahaetulla prasina (Boie, 1827)

Coelognathus flavolineatus (Schlegel, 1837)

Calamaria linnaei (Boie, 1827)

Calamaria lumbricoidea (H. Boie in F. Boie, 1827)

Calamaria modesta (Dumeril, Bibron \& Dumeril, 1854)

Calamaria schlegeli (Dumeril, Bibron \& Dumeril, 1854)

Calamaria virgulata (Dumeril, Bibron \& Dumeril, 1854)

Dendrelaphis pictus (Gmelin, 1789)

Dendrelaphis subocularis (Boulenger, 1888

Gongylosoma baliodeirus (Boie, 1827)

Gonyosoma oxycephalum (Boie, 1827)

Lycodon subcinctus (Boie, 1827)

Ptyas carinata (Guther, 1858)

Ptyas korros (Schlegel, 1837)

Oligodon purpurascens (Schlegel, 1837)

Green Crested Lizard

Great Crested Canopy Lizard

Fringed Flying Dragon

Common Flying Dragon

Chameleon Forest Dragon

Kuhl's Anglehead Lizard

Indonesian False Bloodsucke

Marbled Bow-fingered Gecko

Bow-fingered Gecko

Common Four-clawed Gecko

Tokay Gecko

Common House Gecko

Indo-pacific Gecko

Asian House Gecko

Asian Grass Lizard

Common Mabuya

Bowring's Supple Skink

Java Forest Skink

Common Water Monitor

Reticulated Python

Malayan Vine Snake

Gunther's Whip Snake

Yellow-striped Trinket Snake

Linnaeus's Reed Snake

Variable Reed Snake

Yellow-spotted Reed Snake

Red-headed Reed Snake

Short-tailed Reed Snake

Common Bronze-back

Mountain Bronzeback Tree Snake

Orange-bellied Snake

Red-tailed Racer

White-banded Wolf Snake

Keeled Rat Snake

Ular koros/Oray sawah

Purple Kukri Snake

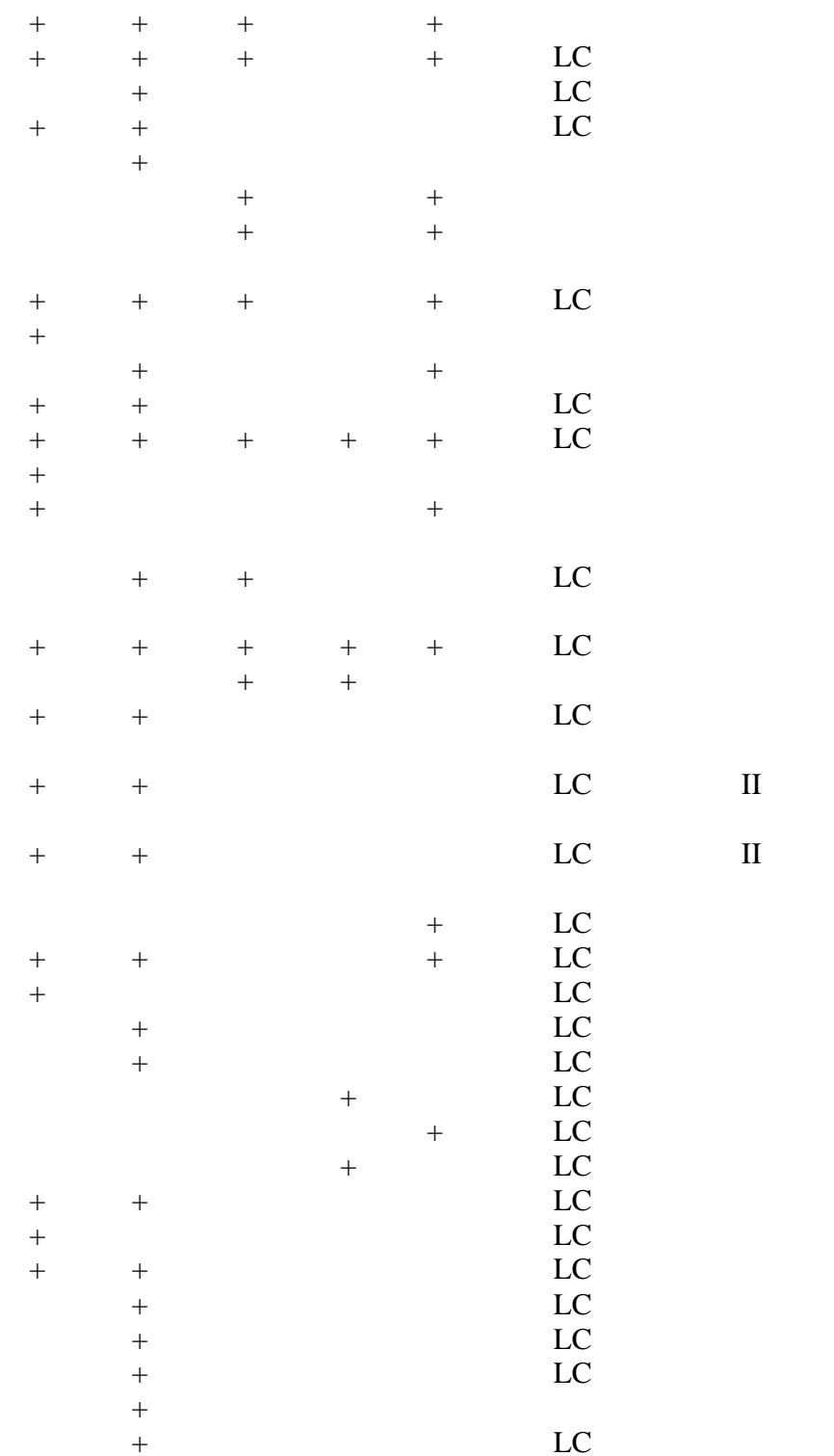




\begin{tabular}{|c|c|c|c|c|c|c|c|c|}
\hline \multicolumn{9}{|l|}{ Viperidae } \\
\hline Trimeresurus puniceus (Boie, 1827) & Javanese Pit Viper & & + & & & & $\mathrm{LC}$ & \\
\hline \multicolumn{9}{|l|}{ Elapidae } \\
\hline Calliophis bivirgatus (Boie, 1827) & Blue Coral Snake & & & & & + & & \\
\hline Bungarus candidus (Linnaeus, 1758) & Malayan Krait & + & + & & & & $\mathrm{LC}$ & \\
\hline Calliophis intestinalis (Laurenti, 1768) & Banded Malaysian Coral Snake & + & & & & + & $\mathrm{LC}$ & \\
\hline Naja sputatrix (Boie, 1827) & Southern Indonesian Spitting Cobra & + & & & & & $\mathrm{LC}$ & \\
\hline Ophiophagus hannah (Cantor, 1836) & King Cobra & + & + & & & & VU & II \\
\hline \multicolumn{9}{|l|}{ Natricidae } \\
\hline Enhydris plumbea (Boie, 1827) & Rice Paddy Snake & & + & & & & $\mathrm{LC}$ & \\
\hline Psammodynastes pulverulentus (Boie, 1827) & Common Mock Viper & & & + & & & & \\
\hline Rhabdophis chrysargos (Schlegel, 1837) & Speckle-bellied Keelback & & + & + & + & + & $\mathrm{LC}$ & \\
\hline Rhabdophis subminiatus (Schlegel, 1837) & Red-necked Keelback & + & + & & & & $\mathrm{LC}$ & \\
\hline Xenochrophis trianguligerus (Boie, 1827) & Red-sided Keelback Water Snake & + & + & & & + & $\mathrm{LC}$ & \\
\hline \multicolumn{9}{|l|}{ Pareatidae } \\
\hline Pareas carinatus (Boie, 1828) & Keeled Slug-eating Snake & & + & & & & $\mathrm{LC}$ & \\
\hline \multicolumn{9}{|l|}{ Typhlopidae } \\
\hline \multirow[t]{2}{*}{ Ramphotyphlops lineatus (Schlegel, 1839) } & Lined Blind Snake & & + & & & & $\mathrm{LC}$ & \\
\hline & Total & 35 & 51 & 29 & 16 & 37 & & \\
\hline
\end{tabular}

Note: CLT: Ciletuh (2017), CSK: Cisokan (2018), KMJ: Kamojang (2017), DRJ: Darajat (2018), GS: Gunung Salak (2018) Notes: ${ }^{1}$ Endemic species to Java Island, ${ }^{2}$ Endemic species to Java-Bali Island 
Table 4. Herpetofauna distribution based on elevational range

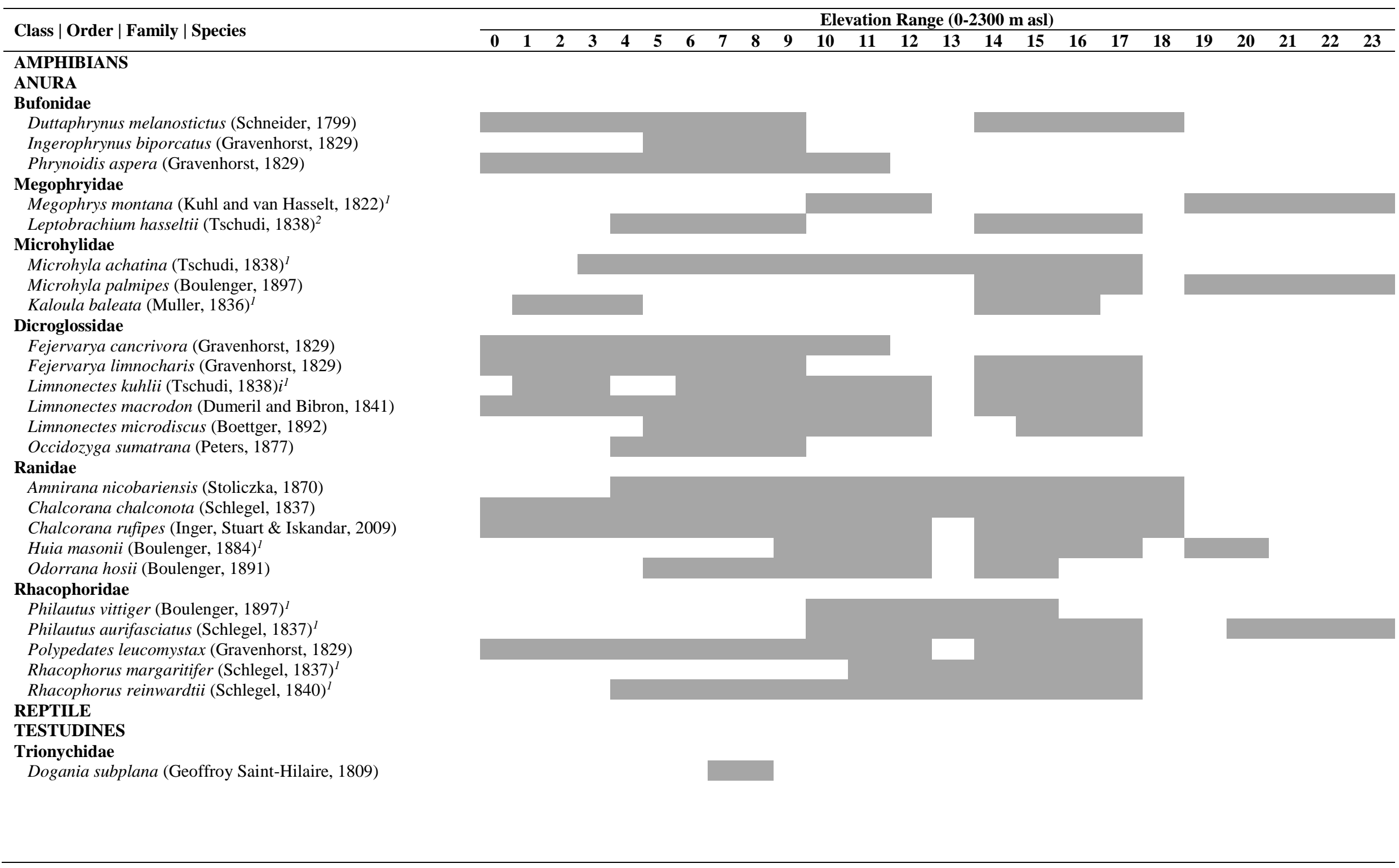




\section{SQUAMATA}

\section{Agamidae}

Bronchocela cristatella (Kuhl, 1820)

Bronchocela jubata (Dumeril \& Bibron, 1837)

Draco fimbriatus (Kuhl, 1820)

Draco volans (Common Flying Dragon) ${ }^{2}$

Gonocephalus chamaeleontinus (Laurenti, 1768)

Gonocephalus kuhlii (Schlegel, 1851)

Pseudocalotes tympanistriga (Gray, 1831) ${ }^{l}$

\section{Gekkonidae}

Cyrtodactylus marmoratus (Griffith and Pidgeon, 1831)

Cyrtodactylus sp. (Gray, 1827)

Gehyra mutilata (Wiegmann, 1834)

Gekko gecko (Linnaeus, 1758)

Hemidactylus frenatus (Dumeril \& Bibron, 1836)

Hemidactylus garnotii (Dumeril \& Bibron, 1836)

Hemidactylus platyurus (Schneider, 1797)

Lacertidae

Takydromus sexlineatus (Daudin, 1802)

\section{Scincidae}

Eutropis multifasciata (Kuhl, 1820)

Lygosoma bowringii (Gunther, 1864)

Sphenomorphus sanctus (Dumeril \& Bibron, 1839)

\section{Varanidae}

Varanus salvator (Laurenti, 1768)

\section{Pythonidae}

Malayopython reticulatus (Schneider, 1801)

Colubridae

Ahaetulla mycterizans (Linnaeus, 1758)

Ahaetulla prasina (Boie, 1827)

Coelognathus flavolineatus (Schlegel, 1837)

Calamaria linnaei (Boie, 1827)

Calamaria lumbricoidea (H. Boie in F. Boie, 1827)

Calamaria modesta (Dumeril, Bibron \& Dumeril, 1854)

Calamaria schlegeli (Dumeril, Bibron \& Dumeril, 1854)

Calamaria virgulata (Dumeril, Bibron \& Dumeril, 1854)

Dendrelaphis pictus (Gmelin, 1789)

Dendrelaphis subocularis (Boulenger, 1888)

Gongylosoma baliodeirus (Boie, 1827)

Gonyosoma oxycephalum (Boie, 1827)

Lycodon subcinctus (Boie, 1827)

Ptyas carinata (Guther, 1858)

Ptyas korros (Schlegel, 1837)

Oligodon purpurascens (Schlegel, 1837)
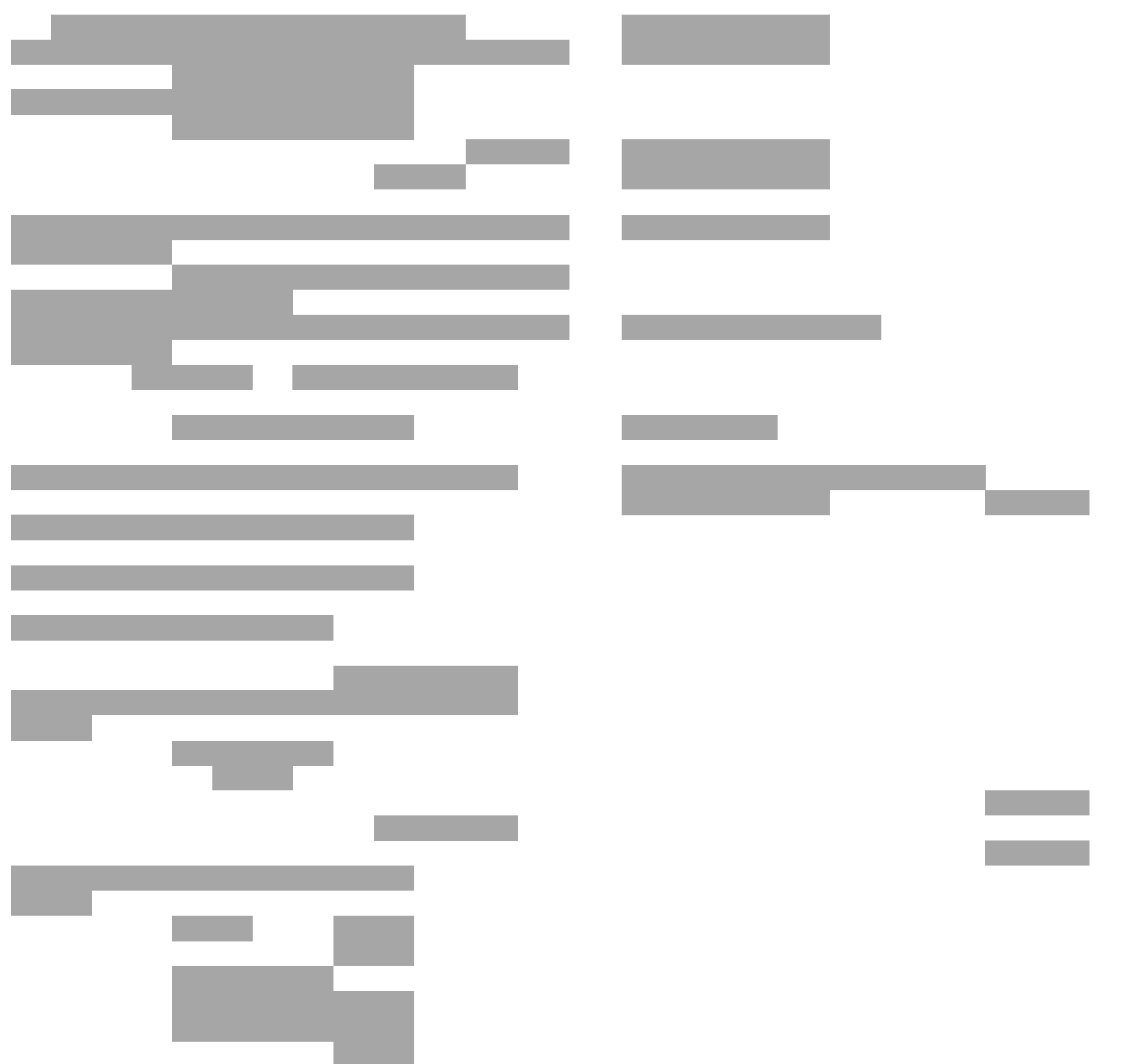
Viperidae

Trimeresurus puniceus (Boie, 1827)

Elapidae

Bungarus bivirgatus

Bungarus candidus (Linnaeus, 1758)

Calliophis intestinalis (Laurenti, 1768)

Naja sputatrix (Boie, 1827)

Ophiophagus hannah (Cantor, 1836)

\section{Natricida}

Enhydris plumbea (Boie, 1827)

Psammodynastes pulverulentus (Boie, 1827)

Rhabdophis chrysargos (Schlegel, 1837)

Rhabdophis subminiatus (Schlegel, 1837)

Xenochrophis trianguligerus (Boie, 1827)

Pareatidae

Pareas carinatus (Boie, 1828)

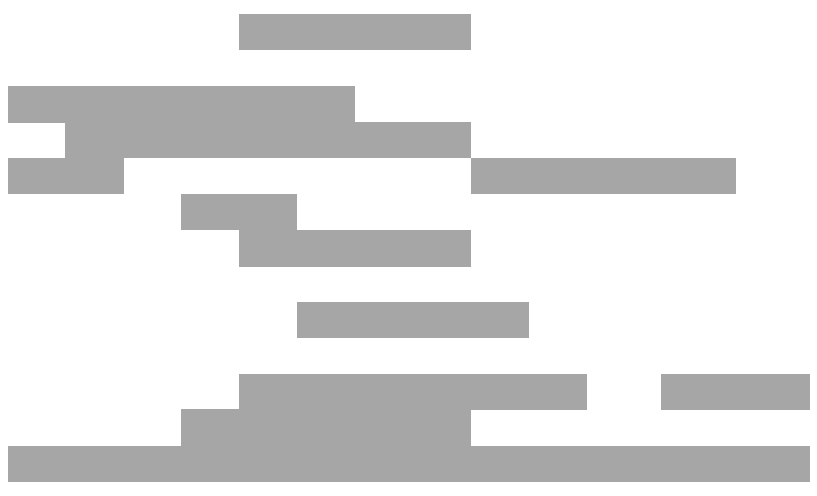

Typhlopidae

Ramphotyphlops lineatus (Schlegel, 1839)

Source: Primary Data (2017-2018); note: 0-23 = elevation range (x100) 


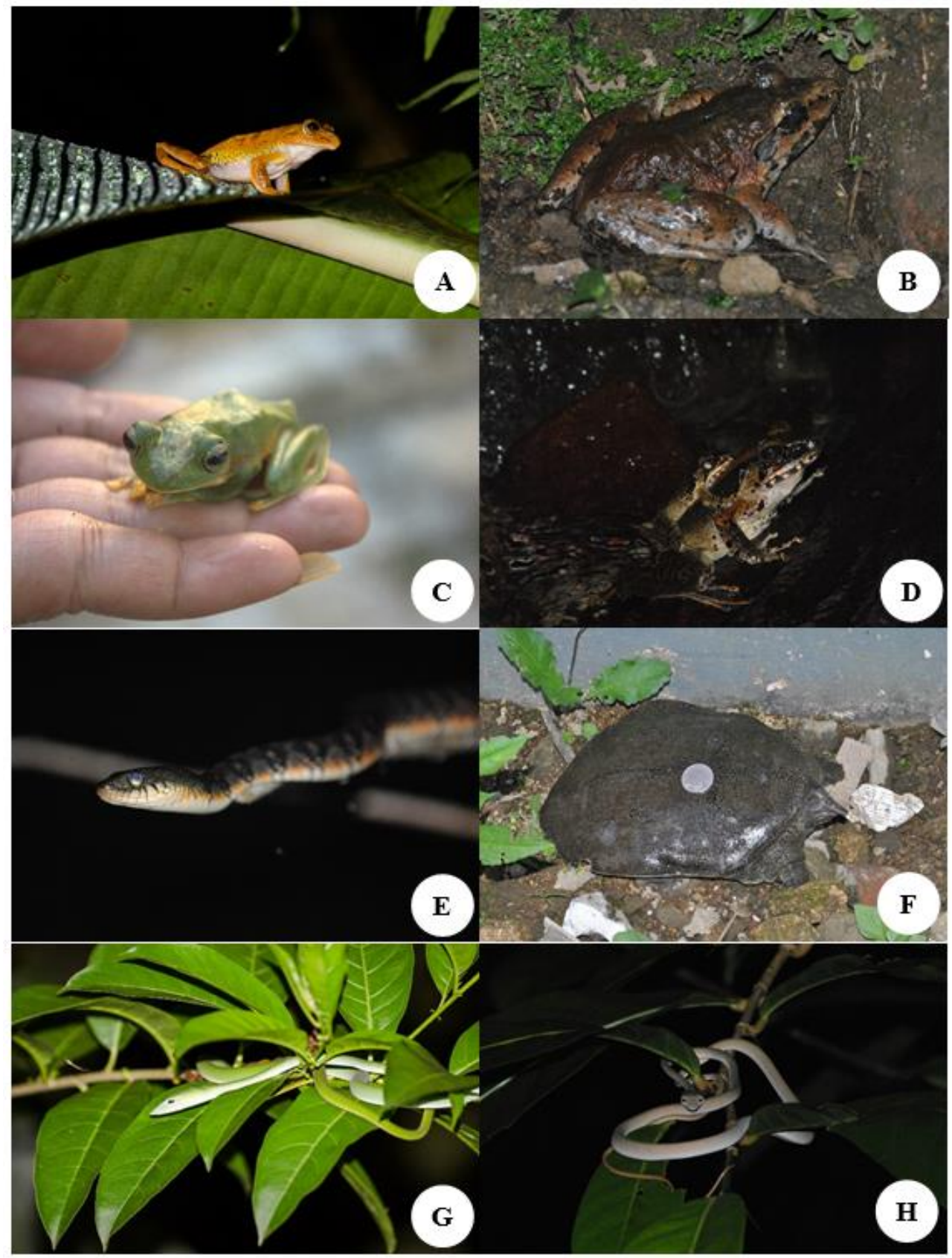

Figure 2. Documentation of herpetofauna species; A. Rhacophorus margaritifer, B. Limnonectes macrodon, C. Rhacophorus reinwardtii, D. Huia masonii, E. Xenochrophis trianguligerus, F. Dogania subplana, G. Ahaetulla prasina, H. Ahaetulla mycterizans

Amphibians were most commonly found at 400-1200 m asl and 1400-1700 m asl. Reptiles were most commonly found in 400-900 $\mathrm{m}$ asl. Based on the elevation of the mountain forest subzone, herpetofauna is more commonly found at elevations $<1000 \mathrm{~m}$ asl than at higher elevations (1500-2400 $\mathrm{m}$ asl), which indicates that the higher the elevation, the fewer species are found (Table 2).

Liem (1971) stated that the higher the altitude of a place, the rarer species. Table 4 shows certain species found at an altitude of $\geq 1900 \mathrm{~m}$ asl, including Megophrys montana, Microhyla palmipes, Huia masonii, Philautus aurifasciatus, Eutropis multifasciata, Lygosoma bowringii, Calamaria modesta, Calamaria schlegeli, and Rhabdophis chrysargos. The differences in the richness and abundance in each region were predicted to affect environmental conditions and the surrounding vegetation (Riyanto and Trilaksono 2012). Water has an essential role in maintaining the humidity that benefits several herpetofauna species, such as amphibians. According to Wanger et al. (2011) and Kwatrina et al. (2019), the moist microhabitat, due to the tight canopy cover and lots of litter, becomes an influential factor on herpetofauna, especially for amphibians. 
Species with high conservation status (based on IUCN and CITES), such as Rhacophorus reinwardtii, were located in Cisokan, Kamojang, and Gunung Salak at 400$1700 \mathrm{~m}$ asl. Huia masonii was found in all locations except Ciletuh at an altitude of 900-1200 m asl, 1400-1700 m asl, and 1900-2000 m asl. Philautus vittiger was only located on Gunung Salak at an altitude of 1000-1500 m asl. Varanus salvator was located in Cisokan and Ciletuh at an altitude of 0-900 m asl. Malayophyton reticulatus was found in Cisokan and Ciletuh at an altitude of 0-700 $\mathrm{m}$ asl.

According to Vega-Trejo et al. (2013), the vegetation type was directly associated with elevation. We often observed the same species of amphibians and reptiles in vegetation types at similar elevations. However, the composition and abundance at lower elevations in pine-oak or oak-pine mixed forests and riparian vegetation differed substantially from higher elevations in coniferous and broadleaf forests. Pike et al. (2011) said that higher sites have more canopy cover, providing lower solar radiation that may affect reptile abundance.

Community structure was similar among vegetation types at the same elevation, although the distance between sites was considerable, and sites were separated either by fragmented landscapes or urban areas. Although it seems that elevation was the most important factor, some species were restricted to particular vegetation types (Vega-Trejo et al. 2013).

In the submontane zone, there are 41 species. According to Brilliant et al. (2012), the lower montane forest area is also known as one of the hotspots of biodiversity. Biodiversity hotspots are areas with relatively intact natural ecosystems and rich biodiversity, and high levels of endemism.

In conclusion, this study demonstrated that the diversity and distribution of amphibians and reptiles in West Java are still underestimated. Not only in conservation areas, amphibians and reptiles also have high species diversity in non-conservation areas. Besides, species diversity depends on land cover and characteristics in a study location, so further studies are needed to support herpetofauna conservation. About the distribution of herpetofauna, the higher the elevation, the less diversity of species is found, so it is necessary to study the factors that influence herpetofauna's distribution.

\section{ACKNOWLEDGEMENTS}

Acknowledgments were given to the Rector of Padjadjaran University, Sumedang, Indonesia through the Academic Leadership Grant Prof. Erri Noviar Megantara, who had supported this research, Centre Environment Sustainability Science (CESS) Padjadjaran University, expertise, and surveyor team. We would also like to thank Eric Meijaard, PAPSI staff (Paguyuban Alam Pakidulan Sukabumi), PT PLN (State Electricity Enterprise) Unit Induk Pembangunan IV, PT PLN-Indonesia Power, and Perhutani.

\section{REFERENCES}

Boruah B, Das GN, Payra A, Dash SK, Pal NS, Das UP, Kar NB, Sethy J, Palei HS, Nandi D, Mishra RK, Rout SD. 2016. Diversity of herpetofauna and their conservation in and around North Orissa University Campus, Odisha, India. NeBio: J Environ Biodivers 7(4): 138-145.

Brilliant R, Varghese VM, Pradeepkumar AP. 2012. Vegetation analysis of Montane forest of Western Ghats. IJBC 4(15): 652-664. DOI: 10.5897/IJBC11.041.

Burlibaşa L, Gavrilă L. 2011. Amphibians as model organisms for study environmental genotoxicity. Appl Ecol Environ Res 9(1): 1-15. DOI: 10.15666/aeer/0901001015.

Cahyadi G, Arifin U. 2019. Potential and challenges on amphibians and reptiles research in West Java. Biodjati 4(2): 149-162. DOI: 10.15575/biodjati.v4i2.4820.

Carlsson G, Tydén E. 2018. Development and evaluation of gene expression biomarkers for chemical pollution in common frog (Rana temporaria) tadpoles. Environ Sci Pollut Res 25: 33131-33139. DOI: 10.1007/s11356-018-3260-z.

Carpio AJ, Cabrera M, Tortosa FS. 2015. Evaluation of methods for estimating species richness and abundance of reptiles in olive groves. Herpetol Conserv Biol 10(1): 54-63.

Cassani JR, Croshaw DA, Bozzo J, Brooks B, Everham III EM, Ceilley DW, Hanson D. 2015. Herpetofauna community change in multiple habitats after fifteen years in a Southwest Florida Preserve, USA. PLoS ONE 10(5): e0125845. DOI: 10.1371/journal.pone.012584.

Das I, van Dijk PP. 2013. Species richness and endemicity of the herpetofauna of South and Southeast Asia. Raffles Bull Zool 29: 267277.

Hamidy A, Munir M, Mumpuni, Rahmania M, Kholik AA. 2018. Detection of cryptic taxa in the genus Leptophryne (Fitzinger, 1843) (Amphibia; Bufonidae) and the description of a new species from Java, Indonesia. Zootaxa 4450(4): 427-444. DOI: 10.11646/zootaxa.4450.4.2.

Hartmann L, Mecke S, Kieckbusch M, Mader F, Kaiser H. 2016. A new species of Bent-toed gecko, genus Cyrtodactylus Gray, 1827 (Reptilia: Squamata: Gekkonidae), from Jawa Timur Province, Java, Indonesia, with taxonomic remarks on C. fumosus (Müller, 1895). Zootaxa: 4067(5): 552-568. DOI: 10.11646/zootaxa.4067.5.2.

Hayes MP, Pounds JA, Timmerman WW. 1989. An Annotated List and Guide to the Amphibians and Reptiles of Monteverde Costa Rica. Miami University. DH Taylor, Oxford.

IUCN [International Union for Conservation of Nature]. 2021. The IUCN Red List of Threatened Species Version 2021-1. [September 20, 2021]

Karthik P, Kalaimani A, Nagarajan R. 2018. An inventory on herpetofauna with emphasis on conservation from Gingee Hills, Eastern-Ghats, Southern India. Asian J Conserv Biol 7(1): 2-16.

Kieckbusch M, Mecke S, Hartmann L, Ehrmantraut L, O'Shea M, Kaiser H. 2016. An inconspicuous, conspicuous new species of Asian pipesnake, genus Cylindrophis (Reptilia: Squamata: Cylindrophiidae), from the South Coast of Jawa Tengah, Java, Indonesia, and an overview of the tangled taxonomic history of C. ruffus (Laurenti, 1768). Zootaxa 4093(1): 1-25. DOI: 10.11646/zootaxa.4093.1.1.

Kwatrina RT, Santosa Y, Bismark M, Santoso N. 2018. The impact of oil palm plantation establishment on the habitat species diversity, and feeding guild of mammals and herpetofauna. Biodiversitas 19(4): 1213-1219. DOI: 10.13057/biodiv/d190405.

Liem DSS. 1971. The frogs and toads of Tjibodas National Park Mt. Gede, Java, Indonesia. Philipp J Sci 100(2): 131-161.

Natusch DJD, Lyons JA. 2012. Exploited for pets: The harvest and trade of amphibians and reptiles from Indonesian New Guinea. Biodivers Conserv 21(11): 2899-2911. DOI: 10.1007/s10531-012-0345-8.

Pike DA, Webb JK, Shine R. 2011. Removing forest canopy cover restores a reptile assemblage. Ecol Appl 21(1): 274-280. DOI: 10.1890/09-2394.1.

Pounds JA, Bustamante MR, Coloma LA, Consuegra JA, Fogden MP, Foster PN, La Marca E, Masters KL, Merino-Viteri A, Puschendorf R, Ron SR, Sanchez-Azofeifa GA, still CJ, Young BE. 2006. Widespread amphibian extinctions from epidemic disease driven by global warming. Nature 439: 161-167. DOI: 10.1038/nature04246.

Priambodo B, Permana H, Akhsani F, Indiwati SE, Wangkulangkul S, Lestari SR, Rohman F. 2019. Characteristics of water sources in 
Malang, based on the diversity, community structure, and the role of herpetofauna as bioindicators. EurAsian J BioSci 13: 2279-2283.

Riyanto A, Bauer AM, Yudha DS. 2014. A new small karts-dwelling species of Cyrtodactylus (Reptilia: Squamata: Gekkonidae) from Java, Indonesia. Zootaxa 3785(4): 589-599. DOI 10.11646/zootaxa.3785.4.7.

Riyanto A, Grismer LL, Wood PL. 2015. The Fourth Bent-toed gecko of the genus Cyrtodactylus (Squamata: Gekkonidae) from Java, Indonesia. Zootaxa 4059(2): 351-363. DOI 10.11646/zootaxa.4059.2.6

Riyanto A, Kurniati H. 2014. Three new species of Chiromantis Peters 1854 (Anura: Rhacophoridae) from Indonesia. Russ J Herpetol 21(1): 65-73.

Riyanto A, Munir M, Martamenggala AIS, Fitriana YS, Hamidy A 2019a. Hiding in plain sight on Gunung Muria: A new species and first record of Rock gecko (Cnemaspis Strauch, 1887; Squamata, Gekkonidae) from Java, Indonesia. Zootaxa 4608(1), 155-173. DOI: 10.11646/zootaxa.4608.1.9.

Riyanto A, Sulaeman TN, Rachman N, Chaidir DM, Trilaksono W, Farajalah A. 2019b. Short Communication: Herpetofauna diversity, potential ecotourism in Mount Galunggung, West Java, Indonesia. Biodiversitas 20(4): 1173-1179. DOI: 10.13057/biodiv/d200433.

Riyanto A, Trilaksono W. 2012. Herpetofauna community in the East Slope of Mount Slamet, Central Java. In (eds). Mount Slamet Ecology: Geology, Climatology, Biodiversity and Social Life Dynamics. LIPI Press, Jakarta. [Indonesian]

Riyanto A. 2011. Herpetofaunal community structure and habitat associations in Gunung Ciremai National Park. West Java. Indonesia. Biodiversitas 12(1): 38-44. DOI: 10.13057/biodiv/d120108.
Rozi ZF, Samitra D. 2020. Amphibians diversity in Sulap Hill and Watervang DAM, Lubuklinggau. Biodjati 5(1): 153-163. DOI: 10.15575/biodjati.v5i1.5340.

Samitra D, Rozi ZF. 2020. Short Communication: The herpetofauna around human settlements in Lubuklinggau City, South Sumatra, Indonesia: Composition and diversity. Biodiversitas 21(4): 143-1437. DOI: $10.13057 /$ biodiv/d210422.

Scott NJ Jr. 1976. The Abundance and diversity of the herpetofaunas of tropical forest litter. Biotropica 8: 41-58. DOI: 10.2307/2387818.

Shaney KJ, Wostl E, Hamidy A, Kurniawan N, Harvey MB, Smith EN. 2017. Conservation challenges regarding species status assessments in biogeographically complex regions: Examples from overexploited reptiles of Indonesia. Oryx 51(4): 627-638. DOI: 10.1017/S0030605316000351.

Stevens G. 1992. Elevational gradient in altitudinal range: An extension of rapoport's latitudinal rule to altitude. Am. Nat 140: 60-71. DOI: $10.1086 / 285447$.

Uetz P, Freed P, Hošek J. 2018. The Reptile Database. http://www.reptiledatabase.org. 14 April 2018.

UNEP-WCMC (Comps.) 2021. Checklist of CITES species. CITES Secretariat, Geneva, Switzerland and UNEP-WCMC, Cambridge. http://checklist.cites.org/.

van Steenis CGGJ. 2006. The Mountain Flora of Java. Pusat penelitian Biologi-LIPI, Bogor.

Vega-Trejo R, Trejo I, Flores-Villela OA, Reynoso VH. 2013. Amphibian and reptile community structure in Pristine Coniferous Forests: Baseline data for conservation studies. Herpetol Conserv Biol 8(3): 622-640.

Wanger TC, Motzke I, Saleh S, Iskandar DT. 2011. The amphibians and reptiles of the Lore Lindu National Park area, Central Sulawesi, Indonesia. Salamandra 47(1): 17-29. 